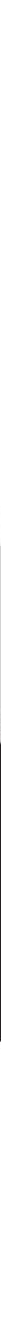


This page intentionally left blank

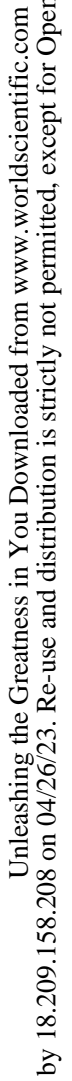


Chapter 1

\section{WHAT IS GREATNESS? THE TEN INGREDIENTS OF GREATNESS}

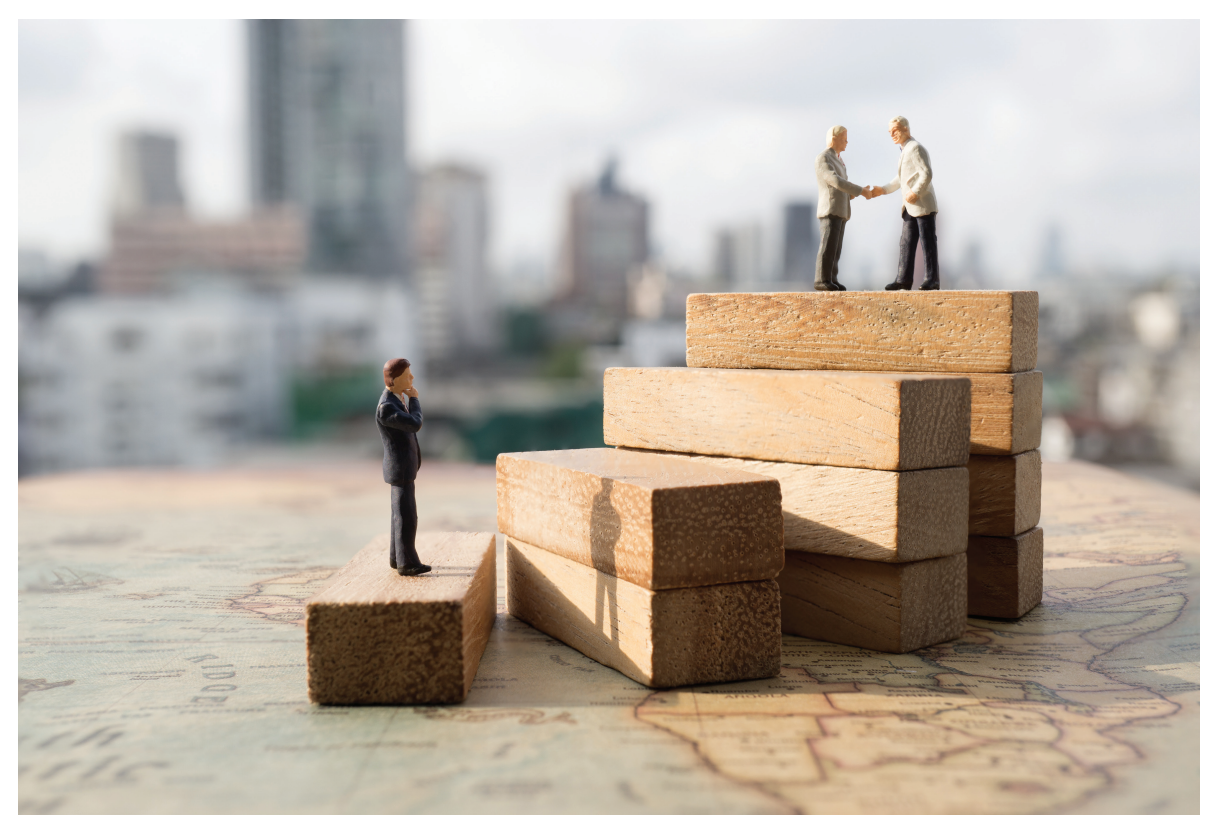

$$
\begin{gathered}
\text { "Success without successors or } \\
\text { a successful system is not success." } \\
\text { Dr. John } \mathbf{~ g g}
\end{gathered}
$$




\author{
"Greatness is a lot of small things \\ done well every day." \\ "You must remain focused on the journey to greatness."
}

\title{
Les Brown
}

Greatness needs to be redefined. Without a proper definition, you can be misled, your priorities misplaced, your efforts misdirected, or worse, you may end up in a life of misguided legacy.

Allow me to share ten facets of greatness.

\section{Greatness is Nurturing Character}

If you define greatness by position, status, size, power, influence and wealth, then you are short-changing yourself. The first facet of greatness has to be character. Throughout history, truly great people are people of great character. We think of Martin Luther King Jr, Mahatma Gandhi, and Nelson Mandela.

Character has to do with integrity. As my good friend Edward Ong, founder of Sutera Harbor, opined, "The world has no shortage of creativity, but of integrity."

Integrity is 'talking the walk, walking the talk and walking the walk.' It is the moral courage to do the right thing constantly in the midst of conflicting and confounding voices.

As author Zero Dean puts it, "Greatness takes persistence. It takes determination. It takes facing our own fears and doing that which is hard and necessary, instead of what is quick and easy. It takes skipping the mystical shortcuts and using your imagination as a map and preview of life's coming attractions."

This becomes more difficult when we are faced with constant pressures to meet shareholders' expectations and bosses' pressures to deliver results year after year.

For Edwin Soeryadjaya, the founding partner of Sarotoga Capital and heir to the Astra Group, a household name known for its integrity, greatness means voluntarily selling off Astra to repay creditors and depositors in full. 
In China, it was a kindly lady, Grandma Chen, a garbage collector, who stopped and rescued Yue Yue, a two-year-old toddler, who had been run over by two trucks, after 18 passers-by had done nothing. When her compassion made headlines in China, many donated money to her. She gave it all away to Yue Yue's mother for her daughter's hospital bill. Unfortunately, Yue Yue did not survive the accident. Grandma Chen did what was right and showed moral courage. When interviewed, she was asked why she had done it, and she simply replied, "I just did it because it was the right thing to do" That is greatness in action.

\section{Greatness is Enjoying Healthier Family Life}

I am reminded of my pro-bono work in mediating between divorcing couples. The story keeps repeating itself.

I was mediating between a multi-millionaire property developer husband and a high-flying banker wife. During the caucus session, the wife confided, "My husband keeps telling my son and me, 'I work very hard. I am building all these empires for you.' Now he has built the empires but we are no longer there to live in them!"

The common justification for making business our number one and chief priority - "I am doing it for the family" - has left too many people family-less.

One young engineer went berserk after his wife decided to end their five-year marriage. They had a three-year-old son. He was so devastated. He wept uncontrollably and inbetween sobs, told me, "I worked so damn hard, working overtime every night, so that we could move from public housing to a private condo. Now I have no one to live with. I neglected my wife and family. The price is too high to pay."

In recent years, we have seen how great men and women have fallen because of failures in marriage and family.

- Oscar Pistorius, who pushed through a double-leg amputation and earned gold medals in the Athens, Beijing, and London Paralympics for his track and field events. On 14 February 2013, he was found guilty of killing his girlfriend, Reeva Steenkamp.

- Ng Boon Gay, the former Central Narcotics Bureau chief in Singapore, lost his job because of alleged corrupt practices for his sexual impropriety with one female Oracle IT executive. Although he 
was acquitted of the charge, he was retired from the Public Service Commission.

- Michael Palmer, Singapore's former Speaker of Parliament and a senior partner of a prestigious law firm, stunned the nation when he made the surprising announcement that he was involved in an extramarital affair with a divorcee named Laura Ong. This brilliant lawyer, caring Member of Parliament and fair-minded Speaker had to resign because of his affair.

How tragic! Certainly, greatness cannot be measured merely by economic terms, career greatness or material success. But I also believe in recovery. These men can regain their greatness when they turn around.

\section{Greatness is Nurturing Friendships}

Jim Baker, former US Secretary of State, once said, "The fleeting aspect of power causes us to understand the importance of lasting personal relationships friendships." Sometimes, past experiences of corporate betrayal scar a person's desire to develop friendships.

People are also fearful of others exploiting their friendships for business. Great leaders are able to distinguish between professional relationships and personal relationships. They tread this line carefully.

Dr. Robert S Weiss, a psychiatrist who has studied the social choices of executives, reports that friendship is an extremely wide discretionary area for the successful executive. Many executives make no time at all for friendship or see this area of their lives as "totally optional."

Friendship has to be cultivated. We have to make time for friends, something many of us find difficult to do in this day of social media, short messages, and emails. My one piece of advice for young people is to make time for friends. Good friends are willing to be honest with you and are not afraid to challenge you.

The Late Prime Minister and Founding Father of Singapore, Mr. Lee Kuan Yew, paid Dr. Goh Keng Swee, his former Deputy, whom he describes as a good friend, the greatest tribute when he retired from politics: "Your biggest contribution to me personally was that you stood up to me whenever you held a contrary view. 
You challenged my decisions and forced me to re-examine the premises on which they were made. Thus, we reached better decisions. This benign tension made our relationship healthy and fruitful."i

I have the honor of sharing my life with a group of friends since the age of fourteen. We belong to a non-profit organization called Eagles Communications. And we have been together for almost five decades - a relationship that is priceless. You can read about this in a later chapter.

\section{Greatness is Doing your Best Through Values and Results}

Phillip Capital Chairman, Lim Hua Min, described the twin 'Doing the Right Thing' and 'Delivering Results' as the two dimensions of trust, which are the 'Alignment of Value' and 'Ability to Deliver'.

For trust to grow, both these aspects must be present. There must be a constant alignment of values on the one hand and the ability to deliver on the other hand. This trust relationship will grow and be sustained 'over time' rather than at 'just a point in time.' This builds consistency and trust over time.

Whether you are a musician, doctor, business owner or athlete, greatness means being the best that you can be through values and results. There is no short cut to greatness. Joseph Schooling is a great example of a world-class swimmer. You must combine passion with commitment and diligence with perseverance.

Joseph Schooling has pursued his Olympic dream since he was six.ii The seed was sown when he had a conversation with his granduncle, Lloyd Valber, Singapore's first Olympian in 1948. ${ }^{\text {iii }}$ Since then, he plunged into swimming, each time imagining himself behind chased by a shark. He opined, "I just need to stay focused and keep finding ways to get better. My goal is to be the best in the world and I train every day to put myself in that position."

\footnotetext{
iVikram Khanna. "The Practical Visionary”. The Business Times. 15-16 May 2010. P 5. Singapore Press Holdings, Singapore.

ii Alvinology. "7 things we all can learn from Joseph Schooling's Olympic win”. 13 Aug 2016. Yahoo News. Available at: https://sg.news.yahoo.com/7-things-learn-joseph-schooling-035546665.html.

${ }^{i i i}$ Chua Siang Yee. "Pain Behind the Glory”. The Straits Times. 21 Aug 2016. SPH, Singapore.
} 
He continues: "I like having people chase me. I like being the fastest... I tried to make a statement with the other guys saying 'you (want) to catch me, you have to come and take it."'iv

Bob Buford, a well-known cable television executive and owner, once said "It's just like a tennis match. When I play, I play my best. I just do."

Being the best is a two-edged sword. It can also drive us to physical and emotional collapse. Former financier Michael Milken worked twenty-hour days and expected the same of his co-workers. He was commonly reported to be ruthless and intimidating when securing a deal.

In this example, there is no concept of temperance. The only motivational banner is "More!" For Milken, the desire for power was limitless, causing him to place no constraints on either his ambitions for growth or the means of achieving growth. It is important that in our striving for excellence, our efforts must be tempered by having good values.

Greatness is finding alignment in "can, want and should." "Can" refers to our competence and talents. "Want" has to do with our motivations and passion. "Should" applies to our values. This will be discussed in the chapter on Finding your Fit.

Becoming the best is the constant commitment to develop our competency, discovering and rekindling our true passion and shaping our core values. When our "can," "want" and "should' are aligned, we are most fulfilled.

\section{Greatness is Developing People}

People development must be your top priority. This is not just propelled by the functionality of performance but it must be a personal value of every leader, regardless of the employee's loyalty.

Parents don't just develop their children for them to perform. They do it for the sake of their children. Similarly with teachers, coaches, and mentors. This must be in our DNA. This is our human stewardship.

You must place a high premium on developing human potential. This is the concept of dignification: treating employees as human beings rather than as cogs in a

${ }^{\text {iv }}$ Chua Siang Yee. "Coping with Life in the fast lane". The Straits Times. 21 Aug 2016. SPH, Singapore. 
money machine, providing them with opportunities to develop skills to accomplish meaningful jobs, and nurturing human potential at every level.

My friend Edward Ong has this philosophy of people development worth emulating:

We provide staff with lots of training. We are not afraid when other hotels poach them. We are delighted because we can train more people and send them out. That's our mindset. We cannot put people under our bondage. We employ 2,000 people. If they have potential for higher positions in other hotels, we bless them. Those who want to stay, we know their hearts. If they go and leave because of money, so be it. We export our staff to the industry.

Unfortunately, some leaders and organizations are not willing to develop and train their people because they feel that they will leave anyway. They see people development as a waste of time or feel exploited by employees.

Being great takes a different approach. As Dr. Edwards Deming, American engineer, professor, and consultant once said, "Did you hire them like that or did you kill them?", with regards to hiring and training individuals.

\section{Greatness is Developing Successors and Successful Systems}

One of parents' greatest joys is to see their children become better than themselves. Fulfillment for teachers is seeing their students excel and develop into men and women of character and competence. One of the greatest accomplishments for any business leader or politician is to build a system for leaders to thrive in; leaders who are able to sustain and develop a better organization than the one the leaders leave behind.

Tom Jones of Epsilon defines success in three ways: "For me, in this company, my success would be to have left three legacies: One, someone to replace me so that the company is not at risk; two, a solid value system that will transcend both them and me in terms of what the company stands for; and three, economic soundness and stability.'

Success without successors or a successful system is not success.

\section{Greatness is Recovering from Failures}

Research done by the Center for Creative Leadership shows that most leaders learn leadership lessons from crises and failures. Certainly, a key success factor of greatness must be resilience. 
Recovery involves confronting our own realities head on.

For Hsieh Fu Hua, Chairman of UOB Bank, a leader should lead from the front in a crisis. He feels that the leader must be more proactive, demonstrate control, galvanize the people and maintain his sense of perspective and make the final call.

Leaders should not play the 'blame-game.' "During such tough times, a leader should confront the problems head-on rather than confronting his people," he said.

During his first stint as CEO of Bangkok Hospital, Dr. Chatree Duangnet confessed he failed miserably as a change leader. He wanted to push through changes in the hospital but found that no one was following him. He had a big ego and a big vision.

He had to change. In making his comeback to Bangkok Hospital a few years later, he did things very differently. He intentionally enabled his key leaders and ensured that they were with him in the vision and transformation. In short, they have to "cross the river together with me", he said. "A leader is successful only when his followers are successful."

Tom Gernedas, a Holocaust survivor who founded a company that pioneered new methods for controlled temperature testing, saw failure as a very human-centered notion: "When we fail in spite of doing our best, it could turn out to be a step towards better things we cannot see at the time of apparent failures."

By his own admission, Edwin Soeryadjaya started to work only at the age of 42 . In fact, people despised him, saying, "You are a playboy, and you don't know how to run a company." According to him, "It was the biggest slap on my face. It was a wake-up call. That was the turning point of my life."

He had to relearn, recoup, recover and rebuild from the crisis. He could not save Astra. But he rose from the ashes of the family's loss in Astra to become one of the most respected and successful entrepreneurs when he started the Saratoga Group.

\section{Greatness is Being Humble}

When you have gone through crises and failures, they will keep you humble. Cultivating humility involves being constantly aware of your own background, foibles, strengths, weaknesses, vulnerabilities, insecurities, setbacks and inadequacies. 
The outworking of our humility is to serve others rather than serve the self.

Greatness is the ability to keep our egos at bay, especially during the pinnacles of success and triumphs. Most successful people become insensitive, believe that normal rules don't apply, and begin to treat people as pawns in their game of life. Success after success can make us arrogant.

Humility is hardest to maintain when you are at the top. That is why most of the time, organizational setbacks, personal crises and health scares help us remember that we are human.

The late Dr. Goh Keng Swee exemplifies this trait, even though he would not tolerate mediocrity. "He was a rigorous mentor, demanding, never stood for any sloppiness in work or argument. But he taught me how to identify an issue from its fundamentals,", said Dr. Tony Tan, President of Singapore.

He was one who liked to get to the root of a problem because he wanted to get feedback from the ground himself. Many will recall that he would cut through red tape and engage the lower ranks. He was famous for spending more time with the frontline managers than the directors and chief executives. He would often pick up the phone and call a line-manager or technician directly to get their feedback. ${ }^{\mathrm{vi}}$

But he confessed that he was also demanding, "I expect every request for finance from me to be properly presented, well argued, with figures to substantiate," Dr. Goh said. vii Humility is not sloppiness or mediocre. It is about maintaining high standards but yet being willing to listen and be open to feedback.

\section{Greatness is Leaving a Legacy of Great Values}

How we end is more important than how we start.

This is true for family, organizations and communities. I want to pass on these tenets of greatness to my children, to the organizations that I lead and to the leaders I have the privilege to coach and mentor.

\footnotetext{
v Nur Dianah Suhaimi. "A rigorous, demanding mentor". The Sunday Times. 16 May 2010. P 8. SPH, Singapore.

${ }^{v i}$ Vikram Khanna. “The Practical Visionary”. The Business Times. 15-16 May 2010. P 5. SPH, Singapore. vii Ibid.
} 
You must embody these values and inculcate these values in others if you are truly great. This is perhaps the most arduous challenge for each one of us.

This is thelegacy that the late Prime Minister, Lee Kuan Yew left behind for Singapore ${ }^{\text {viii: }}$

Give clear signals - don't confuse people.

Be consistent - don't chop and change.

Stay clean - dismiss the venal.

Win respect, not popularity - reject soft options.

Spread benefits - don't deprive the people.

Strive to succeed - never give up.

His story and legacy will be shared in my last chapter, The Greatness of a Great Leader.

I like the founder of Herman Miller, Max De Pree's definition of legacy: "A legacy results from the facts of our behavior that remain in the minds of others, the cumulative informal record of how close we came to the person we intended to be." This is so true in the life of Lee Kuan Yew! I also hope to leave this kind of legacy of greatness. I am sure you want to do the same, and you can.

\section{Greatness is Caring for the Community and the Environment}

Our greatness is never complete if it is self-focused or even family-focused or organization-focused. It was Bill Gates who said he was struck again and again by how important it is to improve the human condition. He demonstrated it by investing most of his wealth in the Bill \& Melinda Gates Foundation.

In addition to making sure the loved ones in his life are happy and cared for, the second critical component of success for Gates is to make the world a better place. Gates writes, "It is also nice to feel like you made a difference - inventing something or raising kids or helping people in need."

- In 2000, he set aside US $\$ 1$ billion to help 20,000 young people afford college.

viii Zuraidah Ibrahim and Andrea Ong. "Remembering Lee Kuan Yew: A life devoted entirely to Singapore”. The Straits Times. 24 March 2015. SPH Singapore. 
- In 2002, he installed 47,000 computers in 11,000 libraries in all 50 states in USA.

- In 2010, Melinda Gates, Warren Buffett, and Bill Gates launched the Giving Pledge, a commitment by the world's wealthiest people to dedicate most of their wealth to philanthropy.

- In 2010, Bill and Melinda Gates challenged the global health community to declare this the Decade of Vaccines. They pledged $\$ 10$ billion over the next 10 years to help research, develop, and deliver vaccines for the world's poorest countries.

- In 2013 Bill Gates helped launch a $\$ 5.5$ billion effort to eradicate polio by 2018. India was certified polio-free by the World Health Organization, leaving only three countries that have never been free of the disease.

To demonstrate his commitment to greening the environment, in 2006, Bill Gates helped launch TerraPower, a company that aims to provide the world with a more affordable, secure, and environmentally friendly form of nuclear energy. He also created a new fund, Breakthrough Energy Venture (BEV), in 2016 to invest in clean energy breakthroughs. ${ }^{\text {ix }}$

For all that, I have the highest respect for a man like Bill Gates. Truly, as is said, "Great words come from great minds. Great minds come from great hearts."

1. Which aspect of greatness captures your imagination? Why?

2. What is one aspect of greatness that you want to work on?

\section{Action Steps}

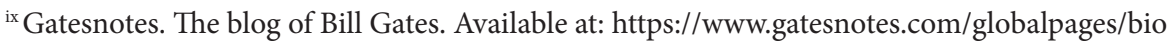




\section{Chapter 2}

\section{UNLOCKING THE \\ GREATNESS ${ }_{I N}$ YOU \\ THE FIVE KEYS TO GREATNESS}

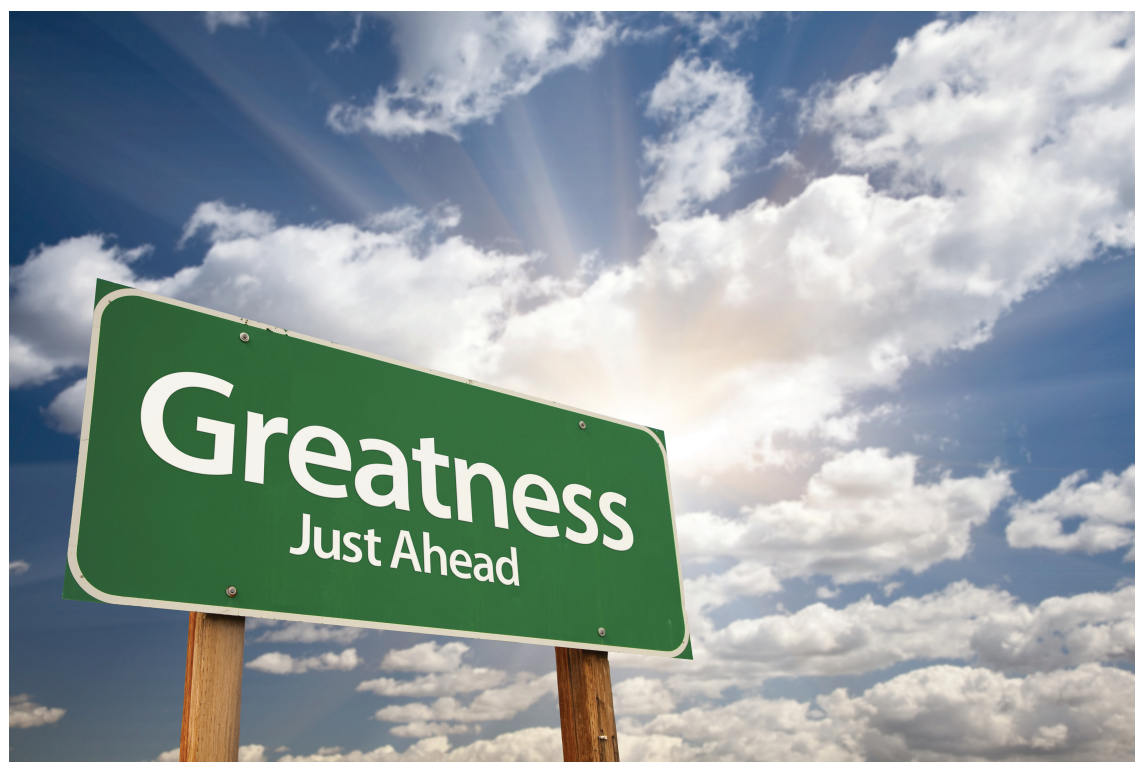

"Greatness is a Choice. Desire, burning desire or holy discontent is the beginning of change to achieving anything beyond the ordinary."

\section{Dr. John Ng}




\section{"You have to fall in love with the process \\ of becoming great."}

\section{Anonymous}

I have been studying the subject of greatness for a long time.

But, I am also dismayed that many people do not achieve greatness. Some haven't the faintest idea of what greatness is. Others choose to under-achieve. Still others decide to stay ordinary. Many start well but are derailed along the way.

But I believe that all of us, especially children, aspire to greatness. Children are curious. They have aspirations. They want to experiment. But somewhere, somehow and someone, often a parent, suppresses or supplants their passion.

I am also disappointed by the many leadership fallouts, especially among highprofile global leaders, who were once lauded as role models in our world.

We see this in the US, where we have the late Kenneth Lay and Jeffrey Skilling of Enron. They were leaders in what was once extolled as the most innovative energy company but which became the biggest corporate fallout in the history of America.

Others like Anthony Weiner, the savvy Democrat Congressman, who was found guilty for 'sexting' and sending nude photos, or Chaka Fattah, Congressman from Philadelphia, who was sentenced to 10 years for racketeering, money laundering and fraud, and William McCormick of CMS Energy, which was found to have questionable practices, also fell in the leadership journey.

The misconduct of the financial industry including the Libor scandal (in the fixing of interest rates) by the world's leading banks has become too familiar and so widespread that it has made corruption the No. 1 problem in the world. When a chief executive of one of the world's biggest and most reputable banks was asked why this was so, his nonchalant excuse was, "We did not do it as bad as the others!" In Asia, Thaksin Shinawatra, business tycoon turned Prime Minister of Thailand, was ousted in a coup and jailed two years for alleged corruption. He then became a fugitive. Most recently, the top Thai monk, the Acting Supreme Patriarch Somdet Phra Maha Ratchamangalacharn, better known as Somdet Chuang, was also investigated by Thai police for alleged corruption. 
In Indonesia, President Suharto, the former President of Indonesia, left a controversial legacy. In January 2017, Ex-Garuda Indonesia CEO, Emirsyah Satar, was charged by Indonesia's KPK (Corruption Eradication Commission) on corruption charges involving the purchase of Rolls-Royce engines for Garuda during his stint as chief executive. This was part of the British investigation into one of Rolls-Royce's executives for paying bribes to secure contracts in countries that include Thailand, Kazakhstan, Azerbaijan, Angola and Iraq.

In China, Zhou Yongkang, who was once part of the Chinese Politburo Standing Committee (the highest political decision-making body), became the most senior official ever convicted of corruption and economic crime.

Bo Xilai, Governor of Chongqing and his estranged wife, Gu Kalai, were sentenced to life imprisonment for the murder of a British subject and for massive corruption. Chen Liangyu, former Governor of Shanghai, was removed from office and charged for misappropriation of a social security sum of US $\$ 400$ million.

In Korea, the ex-President Park Geun-hye was impeached and had to resign from her presidency. She has since been charged formally for 18 criminal charges including coercion, bribery and abuse of power. Together with her was the Chairman of Lotte Group, the largest retail conglomerate, Shin Dong-bin, who was on trial for corruption, and the third-generation scion of the Samsung Group, Lee Jae-Yong, was also on trial for giving bribes to Park.

In India, Vijay Mallya, the tycoon who called himself the 'King of Good Times', was arrested in London for an avalanche of unpaid bills and allegations of fraud.

Even companies like Siemens, JGC (Japan), Snamprogetti (Netherlands), VW (Germany), Sharp (Japan), Samsung (Korea) have not been spared.

Sport has become big business, involving millions of dollars. That is why sportsmen like Lance Armstrong cheated (the seven-time Tour De France champion executed the greatest cheat in cycling history) and Nelson Piquet Jr. succumbed (the Renault F1 driver was ordered to crash so that his team member Fernando Alonso could win the race).

Almost every sports association is tainted with corruption today: FIFA — Federation Internationale de Football Association, the most powerful and influential sport 
organization in the world; UCI - Union Cycliste International, the world cycling association is still recovering from the Lance Armstrong scandal; and most recently IAAF - the International Association of Athletics Federations, is reeling from the doping scandal in Russia, with alleged systematic and state-sponsored corruption and bribery practices.

Sixty-two percent of Americans believe that corruption is widespread across corporate America. According to Transparency International, an anticorruption watchdog, nearly three in four Americans believe that corruption has increased over the last three years.

The temptation to bend the rules is probably highest toward the end of an economic upswing, when executives must be the most creative to keep the stream of profits rolling in. Company executives are paid to maximize profits, not to behave ethically. In the US, the most toxic, no-documentation, reverse amortization, liar loans flourished toward the end of the housing bubble. And frauds are typically discovered only after the booms have turned to bust.

As Warren Buffett famously said, "You only find out who is swimming naked when the tide goes out."

What is most disturbing and frightening is that no country is spared from this scourge and no industry is untouched by this plague. Fraud, bribery and corruption seem to be the new 'normal' for business, politics, and religious organizations. This list of rogues goes on and on. No country, no sport, no organization is spared.

The fallout affects the political, business, and religious sectors in all countries. People are losing trust in government leaders, judges, politicians, athletes, corporate leaders, non-profit organizations and religious leaders.

How do you combat all of these?

First, you must have the right perspective on life and the ingredients for greatness. I would like to share the Five-C model of greatness with you. Whether you are a parent, teacher, athlete, artiste, banker, engineer, fashion designer, biotech specialist, architect, fin-tech specialist, manager or leader, this model applies to you. 
The Five-C model is a model of great leadership, comprising five critical components: Centeredness, Calling, Competency, Character and Community.

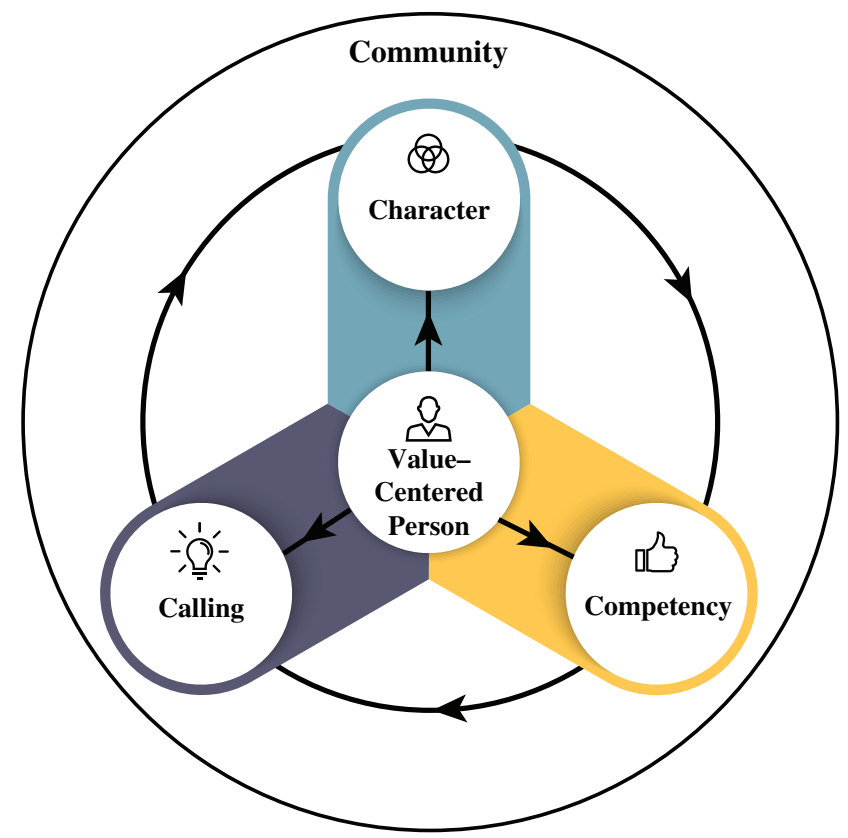

\section{Centeredness (Value of Other-Centeredness)}

"Being deeply loved by someone gives you strength, while loving someone deeply gives you courage."

\section{Lao Tzu}

One core aspect of greatness is to be Value-Centered. Values serve as both the gyroscope and thermostat in our lives. The gyroscope provides stability and a reference point to our lives. Values, like the gyroscope, serve as your stabilizer and keep you on the right path.

Value-centeredness is like a thermostat, not a thermometer. Thermostats regulate the temperature. Similarly, your values help you set the tone and regulate the texture of your life and organizations. Unlike the thermostat, thermometers merely follow the environment. 
Values keep you in balance and guide your decision-making. The 'Who' comes before the 'What'. In other words, 'Being' comes before 'Doing' and your 'Doing' results from your 'Being. The values you hold determine the way you lead.

At the core of this value is to be Other-Centered. From this springs respect, honor and honesty, gratitude and generosity. If you want to be great, you have to love people. The great heart is one that cares for others.

Most of the great people we know are Other-Centered rather than Self-Centered.

We have the highest respect for people who are selfless. We admire teachers who care and spend that extra time to help us through our mathematics examination. We remember the manager who coaches us, develops us and pushes us to greater heights in our career. We value parents who work long hours to eke out a living so that they can pay your school fees. We appreciate young people who are willing to give up lucrative jobs to help the poor and impoverished.

My eldest daughter, Meixi, has lived out this value of Other-Centeredness.

She has lived and worked in Mexico City. She applied for and obtained a place in the Princeton in Latin America Fellowship, which selects and matches recent graduates to work for a year with non-profit organizations in Latin America. Through the fellowship, Meixi had the great privilege of working with Dr. Gabriel Cámara, one of the world's foremost educationists, and his team of teachers, who helped transform 9,000 of the poorest schools and communities in Mexico, using the Tutorial Relationship (TR) pedagogy.

The key concept is to encourage the kids who have mastered or are passionate in a certain topic to tutor other kids. The teacher serves as a coach, friend and facilitator of learning throughout the school. (www.fiftyfold.org)

Meixi was offered a fully-paid scholarship to do her Ph.D. at Cambridge University. But she wanted to go to Mexico City and learn TR from Dr. Camara. Mexico City conjures up all kinds of negative images for me: Mafia-style kidnappings, murders, rapes and robberies. Of course, for my wife Alison and me, the decision was a nobrainer: She should do her Ph.D. at Cambridge!

But her heart was with the poor in Mexico City and she wanted first-hand experience working with Dr. Camara. 
A good friend, Professor Low Guat Tin (who has since retired as a professor in educational leadership from Nanyang Technological University) persuaded us to allow Meixi to go to Mexico. She had heard of Dr. Cámara's work because she knew Pablo Freire, one of the founding fathers of social justice education, who had gone to Mexico and worked with Dr. Cámara. Taking her advice, we reluctantly relented. Rather than being self-obsessed, I am glad that Meixi is making others a core center of her life.

\section{Calling}

Calling creates passion. Author and educator Stephen Covey calls it "finding your own voice." It is finding purpose, meaning and fulfillment in your life. It means understanding yourself, your passion and your destiny.

Calling is your God-given ability to do the job and your God-given enjoyment in doing it. You have a passion in doing it. Of course, passion can be dissipated and has to be nurtured to keep its flame burning.

Michael Novak, in his best-selling book Business as a Calling, describes four characteristics of a calling:

- A calling is unique to you. You find yourself. It is self-knowledge, selfidentity and self-fulfillment.

- A calling requires talent. According to Logan Pearsall Smith, "The test of a vocation is the love of the drudgery it involves."

- A calling reveals its presence by the enjoyment and renewed energies we get when we practice our craft.

- A calling is not easy to uncover. But when you find it, it drives you and your desire to achieve greatness.

Meixi's calling to work in one of the world's toughest communities in Mexico was first fired when we sent her to Hyderabad, India. She was 11 then and went with her brother, Shun, on a trip with a mission organization named Operation Mobilization, under the supervision of my good friend, Rodney Hui.

When Dr. Cámara asked her what motivated her to work in Mexico City, she recalled her trip to India. She said, "The kids in Hyderabad had so much joy even 
though they were so poor. That made me question why I could not enjoy my own school, even though I was so privileged."

That trip also made an indelible memory in her mind and created compassion in her heart. Since then, she has gone every year to Chiang Rai, Thailand, to be with the Lahu children and learn from them. After completing her undergraduate studies at Northwestern University, her calling drove Meixi to become the best in her field and she is pursuing her Ph.D. in Education Science at the University of Washington, Seattle, specializing in leadership education for the indigenous people.

She is so committed that she finds time and space to be with her teachers and students in Thailand, organizing workshops for them, empowering them to excel and applying her studies and research to real-life learning communities. She literally has to fly around half the world to do what she does, two to three times a year, while she is pursuing her Ph.D. That's what calling does for you.

But calling is not enough. When you find your calling, you will do anything to hone your skills and to achieve your goals.

\section{Competency}

Competency is the accumulation of knowledge and skills in what you do. It comprises both professional competency and leadership competency. It involves both hard and soft skills.

Hard skills have to do with the professional or technical aspect of the business. If you are in the banking industry, you need banking competency, like financial analysis, banking regulations, and business accounting. If you are in retail, you need retail knowledge and skills, like selling, negotiation, and product knowledge. You must have a working knowledge of the business.

But technical or professional knowledge itself is incomplete and insufficient. We need leadership competency, which is the softer aspect of the work, which may include a combination of influencing, coaching, team leadership and people management skills.

Using Meixi as an example, for her to master her craft in TR was not sufficient. While she was in Mexico, she had to travel to many cities and villages to learn to 
relate to people from different villages, cities and communities. She had to learn to work with students, colleagues, local teachers, community leaders from diverse cultures and ethnicity.

Often, she has to travel alone on buses to the remotest of regions and at times, to the most dangerous of villages so that she can immerse herself in their cultures and learn to be culturally sensitive to experience the transformative nature of TR. TR will not be effectively executed if she lacks people management skills.

Her calling was matched by her desire to learn and work with people of diverse cultures and different strata of society. This is the soft part of competency.

After returning from Mexico, she started a non-for-profit organization, Fiftyfold, with the intent of bringing TR, whose motto is 'Loving to Learn and Learning to Love', to schools in Chiang Rai and Pisanaluk, cities in Thailand.

For the past three years, the result has been stupendous - not only did the local tribal kids enjoy the learning so much, but for the first time, they were empowered to share their learning with their peers. It is her unique combination of both hard and soft skills that make TR so effective.

\section{Character}

Character describes a person's integrity and morality. The word 'character' comes from the Greek word, kharakter, a stamping tool. It describes a person's quality, a distinguishing mark, feature or trait of a person. Two aspects, integrity and morality, are often the missing pieces in greatness.

Most people associate greatness with power and wealth. If you make these two aspects the stamping tool of your life, then you will be defined by them. You become what you worship. That is why, I believe, there is so much derailment and fall-out. It makes you lose perspective and bearing. It makes you short-sighted.

The other aspect of character is integrity. Integrity is wholeness. It is being real and authentic: What you see is what you get.

I have seen how Meixi develops her character. She really loves her work and she really loves to teach. When she conducts TR sessions with teachers and students, she is full of love and joy. She speaks and writes Spanish so that she can communicate 
with the Mexicans. She learnt how to speak and write in Thai so that she can communicate with the people in Thailand. This has made her so loved and accepted by the Mexicans and the Thais.

She interacts with them sincerely, is always willing to listen and learn from them and always ready to impart her knowledge and skills. She doesn't care how much she is paid, where she stays, and what she eats. The money she raises from a philanthropic foundation in Thailand goes towards organizing retreats, resources for the students and paying for her basic travel expenses. One teacher commented, "She's the real thing!"

She has one consistent practice: 'contemplation in action' or examen, a Jesuit tradition. I noticed that she spends much time reflecting and journaling, which are evident in her blog and website posts. This practice has helped her become more focused in what she is doing.

Beyond her reflections, she puts what she has learnt into action. Everything she learns, becomes part of her and her action plan, which she regularly practices and refines until she has perfected the art. That is integrity - being whole and walking her talk. To her, every failure was a learning discovery, every success a gift of grace.

She personifies Zero Dean's perspective of greatness: "Greatness takes persistence. It takes determination. It takes facing our own fears and doing that which is hard and necessary, instead of what is quick and easy. It takes skipping the mystical shortcuts and using your imagination as a map and preview of life's coming attractions."

\section{Community}

To be in community is to have friends: true and honest-to-goodness friends, who will stand with you while others fall away. Having a community of friends will keep you real and accountable. Over the years, I have recognized that friendship is truly important.

To last the long haul and be truly great, you have to cultivate true friendship. It starts with you. You have to be a friend first. Unfortunately, in our fast-paced, timeis-money world, friendship is in short supply. 


\section{What does true friendship look like?}

In four different studies, using samples from Britain, Hong Kong, and Japan, Dr. Michael Argyle and Dr. Monika Henderson, professors from Oxford University, have established five rules of friendship.

\section{Argyle and Henderson Relational Intimacy Scale (Rules of Friendship)}

Please look at each item and circle the number (1 - Almost never, 2 - Very seldom, 3 - Somewhat true, 4 - A great deal, 5 - Almost all the time)

I disclose things that are personal and important to this person.

$\begin{array}{lllll}1 & 2 & 3 & 4 & 5\end{array}$

We hold many common attitudes and values.

$\begin{array}{lllll}1 & 2 & 3 & 4 & 5\end{array}$

I show my true feelings and behave $\begin{array}{lllllll}\text { naturally when I am with him/her. } & 1 & 2 & 3 & 4 & 5\end{array}$ I strive to make him/her happy whenever we are together. $\begin{array}{lllll}1 & 2 & 3 & 4 & 5\end{array}$

I feel very happy whenever I hear of his/her success.

$20-25$ Strong, healthy friendship with spouse

$11-19$ Fairly good friendship with spouse: focus on areas to develop

5 - 10 Poor, badly strained friendship with spouse: discuss with spouse on how to rebuild the relationship

Try doing this survey, see how many true friends you have. If you do not have many, you should start investing the time to cultivate this type of relational intimacy, where... 
...you can disclose personal and important things.

...you share many common attitudes and values.

...you can show your true feelings and real self without feeling that you are being judged or condemned.

...you strive to make the other person happy.

...you genuinely and truly feel joyful when you hear of his/her successes.

Meixi has a penchant for friendships. She makes time for them. Whenever she comes home from the US during her vacation, she will make it a point to connect with friends from high school, her former college mates, the teachers/students from Shuqun Secondary School where she taught for a year, and her mentors in education. She spends time hanging out with them, be it singing karaoke or going out for salsa dances. It helps that she is an extrovert.

To her closer friends, she can be herself and she can share her dreams and fears freely and openly. She discloses herself with them. They do the same with her. There is reciprocity. No wonder she is well-loved by her friends.

But it is not just social. For her work in Thailand, she engages with her staff and board members. She treats all of them as equals, regardless of educational qualification or rank. She discusses ideas and issues with them. She is open and receptive to their suggestions.

She has built a culture of trust and forged very strong relationships with each member of the team, keeping them informed and including them in much of the decision-making to ensure co-ownership of problems and solutions. She interacts well with both the old and the young, treating everyone as friends.

She truly has a community!

Each of these five features of greatness is important. Allow me to articulate what I mean, using the following diagram: 


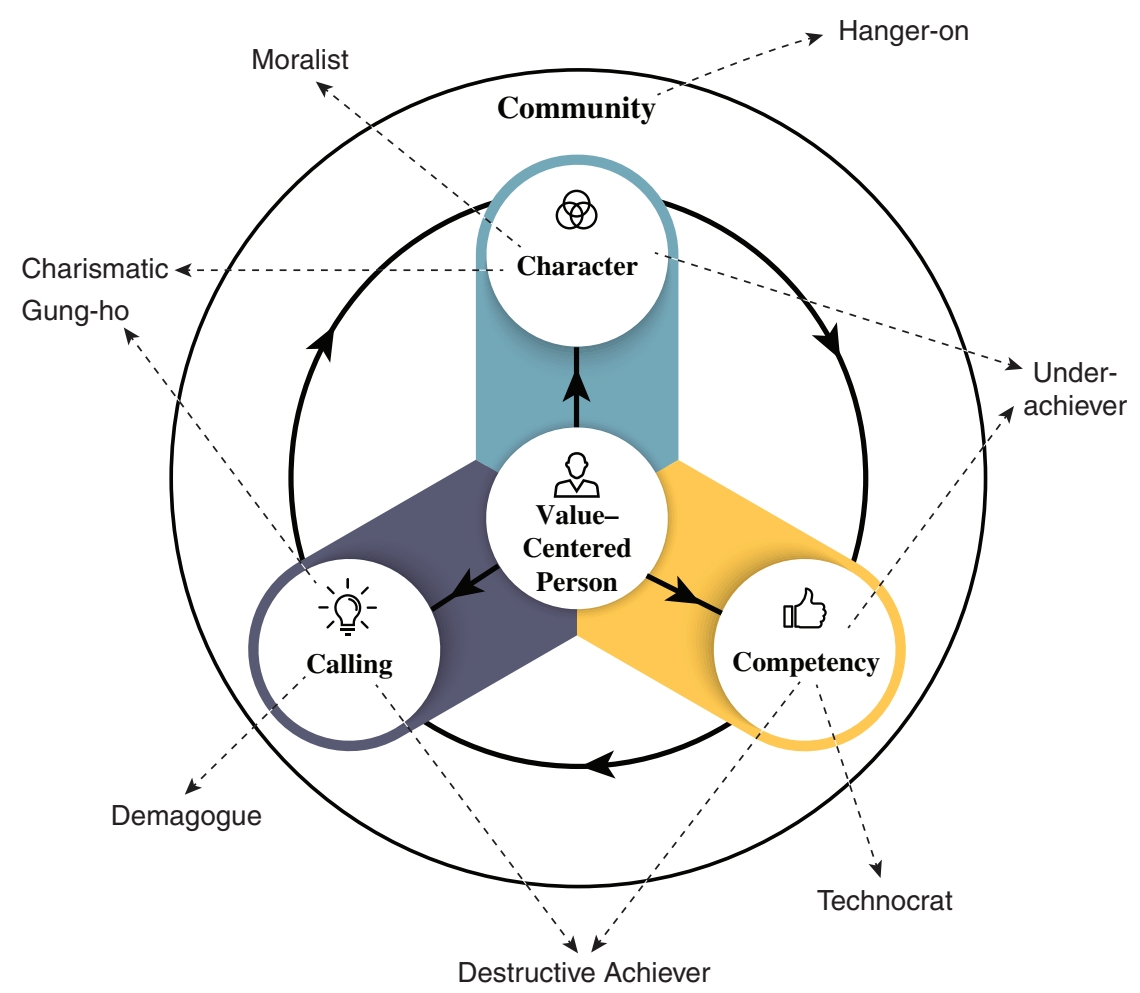

If you have competence, without calling, character and community, you become a technocrat - a functional expert bereft of emotional intelligence.

If you only have character, without calling, competence and community, you become a moralist - dispensing spiritual advice and moral platitudes to your followers, with little credibility because you lack passion and competence in what you do.

If you have calling and competence, without character and community, you become a destructive achiever. I am sure you can cull out examples of this kind of person. The wheeler-dealer investment bankers during the financial crisis of 2008 are fine examples of such people. They are extremely passionate in what they do and they excel in what they do but they lack character (integrity and morality). Hence, they become destructive to the organization, to others and to themselves. If you have community, without centeredness, calling, competence and character, you are just a hanger-on: a friendly but useless bump. 
If you have character and competence, without calling and community, you become a demotivated under-achiever.

If you have character and calling without competence and community, you become a charismatic gung-ho. You are an eager beaver unable to contribute to people and organizations.

If you have centeredness, calling, competence and character without community, you become a lonely solo performer and have no one to share your success or failure with, which is not sustainable in the long run.

Centeredness, calling, competence, character and community: These five features are not techniques or strategies but a frame and perspective that govern your way of life to achieve greatness. All these factors are important.

The real power of greatness lies in the holistic integration of all these five aspects of life.

You must also remember that greatness is a choice and a journey. You must remain focused on that journey to greatness. There is no short cut. At different times, you may lose focus and fail, but you must not give in and give up. It's a long arduous journey worth pursuing and persevering.

You might say I am asking you to bite off more than you can chew. I have this to say: I would rather choke on greatness than nibble on mediocrity.

1. Which aspect of these five factors /Centered, Calling, Competence, Character and Community) is your strength? Why?

2. Which aspect of these five factors /Centered, Calling, Competence, Character and Communityl is your weakness? Why? 